\title{
GAMBARAN PENGETAHUAN RESUSITASI JANTUNG PARU PADA DEWASA MUDA
}

\author{
David Limanan ${ }^{1}$, Susy Olivia Lontoh ${ }^{2}$ \\ ${ }^{1}$ bagian Biokimia dan Biologi Molekuler, Fakultas Kedokteran, Universitas Tarumanagara, Jakarta \\ Email:davidl@fk.untar.ac.id \\ ${ }^{2}$ Bagian Fisiologi, Fakultas Kedokteran, Universitas Tarumanagara, Jakarta \\ Email:susyo@fk.untar.ac.id
}

\begin{abstract}
Cardiopulmonary resuscitation (RJP) is a useful rescue technique in an emergency. In Indonesia data on the level of $C P R$ knowledge in the community, especially young adults are still minimal, so researchers are interested in knowing the level of CPR knowledge in young people, especially students. The purpose of this study was to describe the level of cardiopulmonary resuscitation knowledge and the influence of online training on changes in the level of knowledge about CPR. Research that uses cross sectional descriptive research design to determine the level of knowledge of cardiopulmonary resuscitation and pre-test and post-test design to find out the difference in knowledge levels before being given intervention and after being given CPR knowledge intervention. The online $C P R$ training activity was attended by 287 respondents, consisting of 63 men and 224 women. The age range that took part in this study was 16 years to 29 years, with the majority of respondents aged 18 years. The result of the average pretest score is 46.73 and the posttest average is 53.47. The statistical test showed that there was a significant difference between the respondents' pretest scores compared to the post-test scores (Wilcoxon, $p=0.000$ ). It can be concluded that there was an increase in the knowledge of participants who took part in the CPR training.
\end{abstract}

Keywords: cardiopulmonary resuscitation, training, knowledge

\begin{abstract}
ABSTRAK
Resusitasi jantung paru (RJP) merupakan teknik penyelamatan yang berguna dalam keadaan darurat. Di Indonesia data mengenai tingkat pengetahuan RJP pada masyarakat khususnya dewasa muda masih minim. Tujuan penelitian ini untuk mengetahui gambaran tingkat pengetahuan resusitasi jantung paru dan pengaruh training online terhadap perubahan tingkat pengetahuan mengenai RJP. Penelitian yang menggunakan desain penelitian deskriptif cross sectional untuk menentukan gambaran tingkat pengetahuan resusitasi jantung paru dan pre-test and post-test design untuk mengetahui perbedaan tingkat pengetahuan sebelum diberikan intervensi dan sesudah diberikan intervensi pengetahuan RJP. Kegiatan pelatihan RJP daring diikuti oleh 287 responden, yang terdiri dari 63 laki-laki dan 224 perempuan. Rentang usia yang mengikuti penelitian ini adalah 16 tahun hingga 29 tahun, dengan responden terbanyak berusia 18 tahun. Hasil nilai rata-rata prestest sebesar 46.73 dan nilai rata-rata posttest adalah 53.47. Uji statistik menunjukkan adanya perbedaan bermakna antara nilai pretest responden dibanding nilai post test (Wilcoxon, $\mathrm{p}=0.000$ ). Dapat disimpulkan bahwa terjadi peningkatan pengetahuan peserta yang mengikuti pelatihan RJP.
\end{abstract}

Kata Kunci: resusitasi jantung paru, training, tingkat pengetahuan

\section{PENDAHULUAN}

Henti jantung menjadi masalah kesehatan utama dengan tingkat kelangsungan hidup yang buruk. Resusitasi kardiopulmoner (RJP) yang diberikan secara dini dapat secara signifikan meningkatkan kelangsungan hidup, mempercepat pemulangan pasien dari rumah sakit, dan juga meningkatkan keselamatan pada pasien dengan kejadian henti jantung di luar rumah sakit (OHCA). (Bogle B,2013), (Bryan,2017)

Henti jantung didefinisikan sebagai hilangnya fungsi kontraktil otot jantung dengan tidak adanya sirkulasi darah.(Benjamin,2017). Kasus henti jantung ekstra-rumah sakit lebih sering terjadi daripada didalam rumah sakit dan menjadi salah satu penyebab utama kematian di dunia. (Myat,2018) Saat korban mengalami henti jantung yang terjadi di luar rumah sakit diharapkan dapat menerima bantuan langsung berupa resusitasi jantung paru yang dilakukan oleh orang awam yang terlatih. Resusitasi jantung paru yang langsung diberikan pada kasus henti jantung dapat meningkatkan kelangsungan hidup penderita menjadi 40\%. (Iwami,2012) 


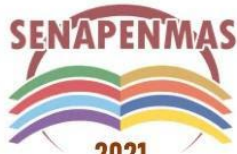

2021

Resusitasi jantung paru menjadi elemen penting dalam rantai kelangsungan hidup di OHCA. Pelatihan terkait resusitasi jantung paru menjadi prioritas pada American Heart Association (AHA) dan organisasi Palang Merah/Bulan Sabit di seluruh dunia sebagai pertolongan henti jantung. (Urban,2013)

Resusitasi jantung paru (RJP) merupakan teknik penyelamatan jiwa yang berguna dalam banyak keadaan darurat. Resusitasi jantung paru sangat penting dalam kasus mati lemas, hampir tenggelam, cedera sengatan listrik, serangan jantung, atau keadaan pernapasan atau detak jantung seseorang telah berhenti. Resusitasi jantung paru melibatkan kombinasi pemberian pernapasan dan kompresi dada, yang berfungsi untuk menjaga darah beroksigen mengalir ke otak dan organ vital lainnya sampai perawatan medis yang lebih definitif dapat mengembalikan detak jantung normal. Ketika jantung berhenti, tidak adanya perfusi darah dapat menyebabkan kerusakan otak ireversibel dalam beberapa menit. Kematian henti jantung akan terjadi dalam 10 menit. (AlTurki,2008)

Beberapa dekade terakhir, kasus henti jantung mengalami peningkatan sehingga diperlukan pelatihan resusitasi jantung paru yang ditargetkan pada dewasa muda khususnya mahasiswa. Tidak hanya petugas pelayanan kesehatan saja, tetapi orang awam, termasuk mahasiswa yang diharapkan untuk memiliki pengetahuan terkait resusitasi jantung paru karena mereka mungkin saja menghadapi situasi serangan jantung setiap saat. (Meissner,2012)

Pengetahuan dan keterampilan mahasiswa terkait resusitasi jantung paru diluar maupun dalam negeri masih rendah. Penelitian yang dilakukan pada mahasiswa fakultas kesehatan di Saudi Arabia tahun 2017 menunjukkan hasil 87,9\% mahasiswa memiliki pengetahuan yang sangat rendah dan $8.9 \%$ mahasiswa berpengetahuan rendah dan hanya $3.0 \%$ mahasiswa yang memiliki pengetahuan baik. (Al-Mohaissen, 2017). Di Indonesia, data terkait tingkat pengetahuan RJP pada masyarakat termasuk mahasiswa masih minim dan berdasarkan permasalahan yang diuraikan di atas peneliti tertarik untuk mengetahui tingkat pengetahuan RJP pada orang muda khususnya mahasiswa. Tujuan penelitian ini adalah mengetahui gambaran tingkat pengetahuan resusitasi jantung paru dan pengaruh pelatihan online terhadap tingkat pengetahuan RJP.

\section{METODE PENELITIAN}

Desain penelitian adalah deskriptif cross sectional untuk menentukan gambaran tingkat pengetahuan resusitasi jantung paru dan pre-test and post-test design untuk mengetahui perbedaan tingkat pengetahuam sebelum diberikan intervensi dan sesudah diberikan intervensi pelatihan RJP secara daring. Penelitian dilakukan secara online dari periode September sampai Oktober 2021 pada dewasa muda khususnya mahasiswa yang telah memenuhi kriteria inklusi. Pengambilan responden dengan cara non-random sampling jenis consecutive sampling dengan kriteria inklusi responden bersedia mengikuti prosedur penelitian, berpartisipasi menjadi subjek penelitian dan mengikuti pelatihan RJP. Responden penelitian diberikan kuisioner melalui G Form yang berisi 9 soal pertanyaan terkait RJP, setelah mengisi kuisioner maka responden penelitian diberikan pelatihan secara online terkait RJP lalu setelah pelatihan RJP responden di minta untuk mengisi kuisioner yang diberikan melalui G Form. Data penelitian terdiri dari data karekteristik responden yaitu frekuensi dan gambaran tingkat pengetahuan responden. Uji Wilcoxon juga dilakukan untuk mengukur tingkat pengetahuan sebelum dan sesuah dilakukan pelatihan. Sebelum dilakukan uji statistik ini, dilakukan uji normalitas data. Uji Wilcoxon dinyatakan berbeda secara bermakna jika nilai $\mathrm{p}<0,05$.

\section{HASIL DAN PEMBAHASAN}

Responden penelitian ini berjumlah 287 orang, yang terdiri dari 63 laki-laki dan 224 perempuan. Rentang usia responden berkisar 16-29 tahun, dengan jumlah terbanyak di usia 18 tahun. Adapun karakteristik usia responden adalah: 2 orang berusia 16 tahun, 29 orang berusia 17 tahun, 102 orang 




2021
Seminar Nasional Hasil Penelitian dan Pengabdian Kepada Masyarakat 2021

Pengembangan Ekonomi Bangsa Melalui Inovasi Digital Hasil Penelitian dan Pengabdian Kepada Masyarakat Jakarta, 21 Oktober 2021

berusia 18 tahun, 46 orang berusia 19 tahun, 55 orang berusia 20 tahun, 39 orang berusia 21 tahun, 8 orang berusia 22 tahun, 2 orang pada kelompok usia 23 dan 25 tahun, serta 1 orang pada kelompok 26 dan 29 tahun (Tabel 1).

Tabel 1. Karakteristik Responden

\begin{tabular}{ll}
\hline Karaktristik & Jumlah $(\%)$ \\
\hline Jenis Kelamin: & \\
Laki-Laki & $63(22 \%)$ \\
Perempuan & $224(78 \%)$ \\
Usia: & \\
16 tahun & $2(0.7 \%)$ \\
17 tahun & $29(10.1 \%)$ \\
18 tahun & $102(35.5 \%)$ \\
19 tahun & $46(16.1 \%)$ \\
20 tahun & $55(19.2 \%)$ \\
21 tahun & $39(13.6 \%)$ \\
22 tahun & $8(2.8 \%)$ \\
23 tahun & $2(0.7 \%)$ \\
25 tahun & $2(0.7 \%)$ \\
26 tahun & $1(0.3 \%)$ \\
29 tahun & $1(0.3 \%)$ \\
\hline
\end{tabular}

Evaluasi pengetahuan responden dilakukan dengan menilai jawaban yang benar dari pertanyaanpertanyaan yang mendasar mengenai RJP. Penilaian pertama dilakukan sebelum pelatihan RJP secara daring untuk menilai pengetahuan dasar dari para responden, dan didapatkan nilai rataratanya sebesar $46.73 \pm 18.29$. Selanjutnya dilakukan penilai pengetahuan responden setelah diberikan pelatihan RJP secara daring untuk menilai perubahan pengetahuan dari responden, dan

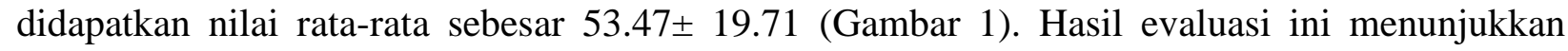
adanya peningkatan rata-rata pengetahuan mengenai RJP sebesar 6.74 (14.42\%). Untuk menilai lebih jauh perubahan yang terjadi maka dilakukan uji statistik, yang sebelumnya dilakukan uji normalitas. Uji normalitas menunjukkan bahwa sebaran data tidak normal, maka untuk uji statistik menggunakan uji Wilcoxon. Hasil uji statistik dengan Wilcoxon didapatkan bahwa terdapat perbedaan bermakna antara pengetahuan responden saat pretest dibanding dengan post test $(\mathrm{p}=0.000)$ (Gambar 2.). Walaupun terdapat peningkatan pengetahuan mengenai RJP dan perubahannya bermakna secara statistik, akan tetapi peningkatan ini dapat memberikan hasil yang lebih besar lagi bila dilakukan secara luring dimana proses pelatihan dapat lebih focus, serta responden dapat langsung mempraktekkan pada manekin RJP. Proses praktek ini akan memudahkan bagi responden untuk menyerap, memproses, mengingat dan mengimplementasikan materi yang diberikan. 


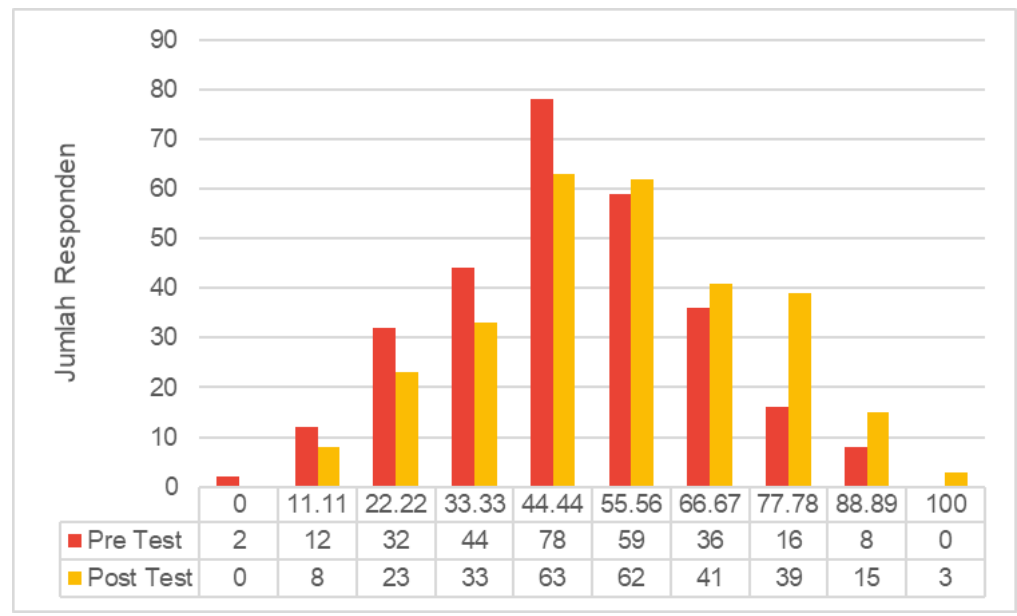

Gambar 1. Sebaran Nilai Pre Test dan Post Test

Test Statistics ${ }^{\mathrm{a}}$

\begin{tabular}{|l|l|}
\hline & $\begin{array}{l}\text { Nilai Posttest - Nilai } \\
\text { Pretest }\end{array}$ \\
\hline$Z$ & \\
Asymp. Sig. (2-tailed) & $-5.710^{\mathrm{b}}$ \\
\hline a. Wilcoxon Signed Ranks Test & .000 \\
b. Based on negative ranks.
\end{tabular}

Gambar 2. Uji Statistik Wilcoxon untuk Pre Test dan Post Test

\section{KESIMPULAN DAN SARAN}

Kegiatan pelatihan RJP daring diikuti oleh 287 responden, yang terdiri dari 63 laki-laki dan 224 perempuan. Rentang usia yang mengikuti penelitian ini adalah 16 tahun hingga 29 tahun, dengan responden terbanyak berusia 18 tahun. Hasil nilai rata-rata prestest sebesar 46.73 dan nilai rata-rata posttest adalah 53.47, maka tampak peningkatan pengetahuan peserta yang mengikuti pelatihan RJP. Uji statistik menunjukkan adanya perbedaan bermakna antara nilai pretest responden dibanding nilai post test (Wilcoxon, $\mathrm{p}=0.000$ ). Selain itu perlu dilakukan penelitian lanjutan dengan proses luring dan praktek pada manekin RJP.

\section{Ucapan Terima Kasih}

Terima kasih penulis sampaikan kepada DPPM UNTAR, Dekan FK UNTAR beserta jajarannya atas bantuan sarana dan prasarana sehingga penelitian ini dapat berlangsung. Pihak yang telah membantu sehingga proses pengambilan data dapat berlangsung dengan baik. Tim Senapenmas UNTAR yang telah memberikan kesempatan kami mengikuti Senapenmas 2021.

\section{REFERENSI}

Al-Mohaissen, MA.(2017).Knowledge and attitudes towards basic life support among health students at a Saudi women's university.Sultan Qaboos University Medical Journal, https://doi.org/10.18295/squmj.2016.17.01.011

Al-Turki YA, Al-Fraih YS, Jalaly JB, Al- Maghlouth IA, AlRashoudi FH, Al-Otaibi AF, et al. (2008). Knowledge and attitudes towards cardiopulmonary resuscitation among university students in Riyadh, Saudi Arabia. Saudi Med J; 29(9): 1306e1309.

Benjamin EJ, Blaha MJ, Chiuve SE, Cushman M, Das SR, Deo R, et al. (2017).Heart disease and stroke statistics - 2017 update: a report from the American Heart Association. Circulation ; 135(10):e146-603. https://doi.org/10.1161/CIR.0000000000000485 


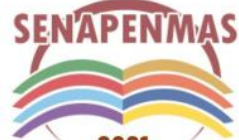

2021
Seminar Nasional Hasil Penelitian dan Pengabdian Kepada Masyarakat 2021

Pengembangan Ekonomi Bangsa Melalui Inovasi Digital Hasil Penelitian dan Pengabdian Kepada Masyarakat Jakarta, 21 Oktober 2021

Bogle B, Mehrotra S, Chiampas G, et al. (2013)Assessment of knowledge and attitudes regarding automated external defibrillators and cardiopulmonary resuscitation among American university students. Emerg Med J;30:837-41.

Bray JE, Smith K, Case R, et al. (2017). Public cardiopulmonary resuscitation training rates and awareness of hands-only cardiopulmonary resuscitation: a cross-sectional survey of Victorians. Emerg Med Australas;29:158-64.

Iwami T, Kitamura T, Kawamura T, Mitamura H, Nagao K, Takayama M, et al. (2012) Chest compression-only cardiopulmonary resuscitation for out-of-hospital cardiac arrest with public access defibrillation: a nationwide cohort study. Circulation. 126(24):2844-51. https://doi.org/10.1161/CIRCULATIONAHA.112.109504

Meissner, TM, Kloppe, C, \& Hanefeld, C. (2012). Basic life support skills of high school students before and after cardiopulmonary resuscitation training: a longitudinal investigation, Scandinavian journal of trauma, resuscitation and emergency medicine, 20 (31), 1-7. https://pubmed.ncbi.nlm.nih.gov/22502917/

Myat A, Song KJ, Rea T. (2018). Out-of-hospital cardiac arrest: current concepts. Lancet ;391(10124):970-9. https://doi.org/10.1016/S0140-6736(18)30472-0

Urban J, Thode H, Stapleton E, et al.(2013) Current knowledge of and willingness to perform Hands-Only ${ }^{\mathrm{TM}}$ CPR in laypersons. Resuscitation, 84:1574-8. 
Seminar Nasional Hasil Penelitian dan Pengabdian Kepada Masyarakat 2021

Pengembangan Ekonomi Bangsa Melalui Inovasi Digital Hasil Penelitian dan

Pengabdian Kepada Masyarakat

Jakarta, 21 Oktober 2021

(halaman kosong) 